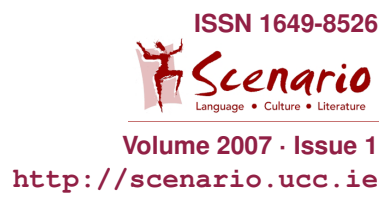

\title{
Foreword
}

\section{Dear Readers of SCENARIO,}

It was in September 2003 during the conference Drama and Theatre in the Teaching and Learning of Languages and Culture in Cork, that the idea of an academic journal for drama/theatre in foreign and second language learning was conceived. Such a journal would explore and build bridges between the performing arts and language pedagogy. Two years later, at the Internationale Deutschlehrertagung 2005 in Graz, the initial concept for such a journal was introduced in the section Drama pedagogy and experimental forms of learning.

The editors are delighted that this project has come to fruition after several years of germination, and that you are now looking at the first edition of SCENARIO. The positive reaction to our first call for papers, entitled Creating Scenario(s) - Drama and Theater for Language Learning, was extremely encouraging and is a sign of a growing interest worldwide in drama and theatre pedagogy.

We hope that the first issue of SCENARIO will be the starting point for an engaged and committed discourse and debate among language researchers and teachers in schools, colleges and universities, drama and theatre educators, as well as theatre professionals.

The profile of SCENARIO (see the journal's homepage) gives an overview of the broad range of possible areas and levels of discussion. We are looking forward with great anticipation to the next batch of manuscripts for our second edition, to be published in autumn 2007 (deadline for articles: July 1).

This first edition includes nine contributions from various perspectives three Irish, three German, two US-American, and one Mexican - featuring dramapedagogical explorations of the teaching and learning of both German and English as a Foreign Language.

Sheree Borge (Cork Institute of Technology, Ireland) and Anna Weiss (Dublin City University, Ireland) report on their experiences with drama education for foreign language learning at institutes of higher education in Ireland. Borge focuses specifically on possible bottlenecks to be overcome by teachers who use drama education for the first time. She analyses her own experiences and offers practical teaching advice for colleagues who are novices in drama education.

After analysing the theoretical foundations of drama education, Weiss demonstrates with practical examples how Irish students of German were introduced step by step to drama education. Based on her own positive experiences, Weiss argues for more dramapedagogical teaching, particularly in universities. 
The following two articles deal with drama education for beginning language learners - a topic heretofore marginalized in academic discourse. Bettina Matthias (Middlebury College, USA) takes a good look at the theoretical and practical considerations of improvisational theatre according to Viola Spolin. Based on her experience with US-American students of German she describes a step-by-step-model for the dramapedagogical teaching of beginners. This model was put to the test during a three-week experiential workshop called "Show, don't tell!" Reflecting on her teaching experiences during this workshop, she emphasizes the importance of kinaesthetic learning, particularly for beginners, to help overcome cognitive and psychological barriers and create new opportunities for experimentation with the unfamiliar language.

Ulrich Wettemann (Centro de Idiomas, Puebla, Mexico) already indicates in the title of his article that beginning foreign language teaching must never be 'dry'. He introduces a dramapedagogical model for the first few lessons in German and shows how ab initio foreign language learning can be made both vibrant and more effective. His teaching model is based on the application of both language acquisition hypotheses and concepts of autonomous learning to dramapedagogical teaching and learning.

The next three articles - by Ulrike Brisson (Worcester Polytechnic Institute, USA), Maria Eisenmann (Pädagogische Hochschule Freiburg, Germany) and Christiane Lütge (Universität Bremen, Germany) - discuss the teaching of literary texts. After advocating drama education for foreign language learning in the $21^{\text {st }}$ century, Brisson concentrates on Schewe and Wilms' (1995) dramapedagogical teaching materials for Alfred Andersch's novel Sansibar oder der letzte Grund. Similar to Borge, her piece analyses her own experiences with dramapedagogical teaching forms. As a supplement to Schewe/Wilms' process-oriented model, Brisson suggests the inclusion of product-oriented assignments, such as a video documentary made by the students, who then analyse their own dramatic improvisations.

Eisenmann weighs in on the ongoing debate concerning Shakespeare's plays as set texts in the last two years of German high schools, specifically whether Shakespeare should be read at all, and if yes, which plays. She notes that pupils are fascinated by the hero's vitality and complexity in "Hamlet," and presents a range of dramapedagogical teaching ideas for the classical drama.

Lütge complements this perspective by combining performative methodology with film studies. English lessons geared towards active examination of Shakespearian plays profit from the combination of dramatic improvisation and discussion of different film versions, and lead to increased pupil involvement and motivation.

Manfred Schewe (University College Cork, Ireland) presents an overview of the connections between drama/theatre and second/foreign language learning since the middle of the $19^{\text {th }}$ century. He concludes by recommending that the issue of how we actually conduct research in our field be integrated far more into academic discourse than has previously been the case. Schewe's overview is complemented by an extensive research bibliography on SCENARIO's 
homepage.

The first issue ends with a review by Birgit Oelschläger (Goethe Institute Berlin, Germany) of the special issue "Theaterspielen" in the journal Frühes Deutsch $(15 / 8,2006)$.

At this point we would like to thank everybody - partners, friends, and colleagues - who helped with the launching of SCENARIO. Special thanks go to Peter Flynn (Computer Centre, UCC) for his expertise, as well as to his colleague Maurice Ryder for helping with the website layout, to Susanne Leutenegger for the composition of the logo, to Frank Prendergast for its graphical realisation, to the students Maria Jenssen and Maria Sinnecker for their reliable and competent assistance, and of course to the 14 members of the international advisory board for the reading and commenting on the manuscripts.

University College Cork helped finance this project through the research fund of the College of Arts, Celtic Studies and Social Sciences and the President's Strategic Fund, jointly applied for by the Department of German and the Board of Drama and Drama and Theatre Studies, UCC.

There was a short interview conducted with the editors of SCENARIO during the launch party. To access the interview, click here.

The Editors

Susanne Even / Manfred Schewe

March 15th, 2007 